\title{
Sequential Saccharification and Simultaneous Fermentation (SSSF) of Sago Hampas for the Production of Bioethanol
}

(Sakarifikasi dan Fermentasi Serentak Berperingkat (SSSF) Hampas Sago untuk Penghasilan Bioetanol)

\author{
Micky VinCENT*, BERRY RENCE ANAK SENAWI, ENNRY ESUT, NORIZAWATI MUHAMMAD Nor \\ \& DAYANG SALWANI AWANG ADENI
}

\begin{abstract}
Bioethanol is a very environmentally friendly liquid biofuel that is not only renewable, but also sustainable. It is currently deemed as a highly suitable additive and substitute energy source to replace fossil based fuel. In this study, bioethanol was produced from sago hampas by using commercial amylase, cellulase and Saccharomyces cerevisiae via sequential saccharification and simultaneous fermentation (SSSF), a modified version of the simultaneous saccharification and fermentation (SSF) process. SSSF was performed on sago hampas at 2.5 and $5.0 \%(\mathrm{w} / \mathrm{v})$ feedstock load for five days. The samples taken from the SSSF broths were analysed via high performance liquid chromatography (HPLC) for ethanol, glucose and acetic acid production. From the results obtained, SSSF with $5.0 \%$ sago hampas loading exhibited the highest ethanol production at $14.13 \mathrm{~g} / \mathrm{L}(77.43 \%$ of theoretical ethanol yield $)$, while SSSF using $2.5 \%$ sago hampas loading produced ethanol at $6.45 \mathrm{~g} / \mathrm{L}(69.24 \%$ of theoretical ethanol yield). This study has shown that ethanol not only can be produced from sago hampas using different enzyme mixtures and S. cerevisiae via SSSF, but yields were also high, making this process highly promising for the production of cheap and sustainable ethanol as fuel.
\end{abstract}

Keywords: Amylase; bioethanol; cellulase sago hampas; sequential saccharification and simultaneous fermentation (SSSF)

\section{ABSTRAK}

Bioetanol adalah bahan api mesra alam yang bukan sahaja boleh diperbaharui, tetapi juga mapan. Ia kini dianggap sebagai bahan api tambahan dan tenaga pengganti yang sangat sesuai untuk menggantikan bahan api berasaskan fosil. Dalam kajian ini, bioetanol dihasilkan daripada hampas sagu dengan menggunakan enzim amilase komersial, selulase dan Saccharomyces cerevisiae melalui proses sakarifikasi dan fermentasi serentak berperingkat (SSSF), iaitu proses sakarifikasi dan fermentasi serentak (SSF) yang telah diubah suai. SSSF telah dijalankan ke atas 2.5 dan $5.0 \%$ $(w / v)$ selama lima hari. Sampel yang diambil daripada kaldu SSSF dianalisis melalui kromatografi cecair prestasi tinggi (HPLC) untuk menentukan kepekatan etanol, glukosa dan asid asetik. Daripada keputusan yang diperoleh, SSSF dengan $5.0 \%$ hampas sagu didapati menghasilkan etanol yang tertinggi iaitu $14.13 \mathrm{~g} / \mathrm{L}(77.43 \%$ daripada hasilan teori etanol), manakala SSSF menggunakan 2.5\% hampas sagu menghasilkan etanol pada $6.45 \mathrm{~g} / \mathrm{L}$ (69.24 \% daripada hasilan teori etanol). Kajian ini telah menunjukkan etanol bukan sahaja boleh dihasilkan daripada hampas sagu menggunakan campuran enzim yang berbeza dan S. cerevisiae melalui SSSF, tetapi penghasilannya juga adalah tinggi, menjadikan proses ini sangat berpotensi untuk menghasilkan etanol dengan kos rendah.

Kata kunci: Amilase; bioetanol; hampas sagu; sakarifikasi dan fermentasi serentak berperingkat (SSSF); selulase

\section{INTRODUCTION}

Bioethanol is a promising substitute to conventional fossil fuels due to its carbon dioxide neutrality and sustainability (Vincent 2010; Vincent et al. 2014). When compared to fossil fuels, bioethanol burns completely and cleanly, producing only water and carbon dioxide, while at the same time enhancing petrol performances (Altintas et al. 2002; Yamashita et al.2010). Most bioethanol is produced by the fermentation of carbohydrate from sugar cane, cane juice, corn starch, grains and potato starch using fermenting organisms such as Saccharomyces cerevisiae and Zymomonas mobilis (Cervero et al. 2010; Vincent et al.2011a). This is known as first generation bioethanol and its production uses crop-based raw materials.
The drawback to first generation bioethanol production is its production cost that is very uneconomical (Vincent et al. 2011b). In addition, the usage of food crops as feedstock for ethanol production is also very controversial as this practice disrupts the food supply chain. Thus, second generation bioethanol was introduced by utilizing lignocellulosic biomass to save cost and to meet the increasing world-wide demand for bioethanol (Vincent et al. 2014). Lignocellulosic biomass is an abundant source of carbohydrate such as cellulose, hemicellulose and can be found in agricultural waste, forest waste and food-based industrial waste as such palm oil empty fruit bunch (EFB) and sago hampas (Adeni et al. 2010; Cervero et al. 2010; Zakaria et al. 2014, 2013). 
Sago hampas is a by-product from sago (Metroxylon sagu) processing factory after starch extraction. According to a study done by Bujang et al. (1996), it was estimated that 7 tons of sago hampas were produced daily from a single sago starch processing mill. This industrial waste is usually washed off into the nearby stream together with waste water which leads to serious environmental issues due to its high chemical oxygen demand (COD) and biological oxygen demand (BOD) content (Adeni et al. 2010).

In this study, sago hampas was utilized to produce ethanol via a process termed sequential saccharification and simultaneous fermentation (SSSF) using commercial amylase, cellulase and S. cerevisiae. Sago hampas is an ideal feedstock for SSSF as this material contains high starch and cellulose concentration of up to 66 and $16 \%$, respectively (Chew \& Shim 1993), which are suitable raw materials for ethanol production. Most of the previous studies on sago hampas conversion only utilize the starch portion of the hampas while the remaining solid residue is discarded, while other studies have been done on the bioconversion of only the solid residue (Adeni et al. 2010; Bujang \& Ahmad 2000). Therefore, in this study, our SSSF was performed to produce ethanol through a sequential process in which the starch of the sago hampas was first liquefied and saccharified, followed by the hydrolysis of the fibre residue. This was achieved by using amylase and cellulase enzyme which function to break down complex polysaccharides into simple sugar and S. cerevisiae as the fermenting microorganism.

\section{MATERIALS AND METHODS}

\section{CHARACTERIZATION OF SAGO HAMPAS}

Sago hampas used in this study was obtained from Pusa, Sarawak. The sago hampas was air dried for three days before it was ground and screened using a 20 mesh sieve. For compositional determination, oven-dried sago hampas were subjected to starch and fibre analyses using the iodine, $\mathrm{ADF}, \mathrm{NDF}$ and Klason lignin assays described previously
(Sluiter et al. 2005; Vogel et al. 1999). Ash content was determined by using standard protocol (Undersander et al. 1993). All analyses to characterize the sago hampas content were performed in triplicates $(n=3)$.

\section{SACCHAROMYCES CEREVISIAE CULTURE PREPARATION}

Saccharomyces cerevisiae (ATCC 24859) was prepared by growing the culture overnight in $100 \mathrm{~mL}$ of sterile LB broth at $32^{\circ} \mathrm{C}$ with constant agitation at $120 \mathrm{rpm}$. The cells were harvested via centrifugation in two $50 \mathrm{~mL}$ conical centrifuge tubes for $5 \mathrm{~min}$ at $6000 \mathrm{rpm}$. The supernatants were discarded and the $S$. cerevisiae cells were added into the batch culture medium during the first stage of the sequential saccharification and simultaneous fermentation (SSSF).

\section{SEQUENTIAL SACCHARIFICATION AND SIMULTANEOUS FERMENTATION (SSSF)}

SSSF was performed in two stages (Figure 1) - stage one was the amylolytic step while stage two was the cellulolytic step. SSSF were carried out in $250 \mathrm{~mL}$ Schott bottles with batch cultures of $150 \mathrm{~mL}$ volume consisting of yeast peptone citrate buffer (YP-CB) solution and sago hampas $(2.5$ and $5.0 \% \mathrm{w} / \mathrm{v})$. After that, the batch culture was autoclaved to provide sterility and to gelatinize the starch. For each set, two batch cultures were prepared and the analyses were performed in duplicate $(n=2)$.

Stage One (Amylolytic Step) Stage one starts after autoclaving, whereby the batch cultures were left to cool down to $60^{\circ} \mathrm{C}$. After the batch culture has reached the designated temperature, amylase (ANG, Novozymes, Bagsvaerd, Denmark) was added and the batch cultures were left to cool down to $37^{\circ} \mathrm{C}$ before adding S. cerevisiae. The batch cultures were then incubated at $37^{\circ} \mathrm{C}(120 \mathrm{rpm})$ under anaerobic condition for three days to allow the SSSF to complete the first stage.

Stage Two (Cellulolytic Step) Stages two commenced on the third day of the SSSF. On the third day $(72 \mathrm{~h})$, most of



FIGURE 1. Sequential saccharification and simultaneous fermentation (SSSF) flow chart 
the gelatinized starch have been liquefied and converted into glucose and ethanol, with the remaining solid remnants mainly cellulosic fibres. Cellulase ( $25 \mathrm{FPU} / \mathrm{g}$ fiber) was then added into the batch culture to digest the fibres at $37^{\circ} \mathrm{C}$ $(150 \mathrm{rpm})$ under anaerobic condition for another 2 days to allow further digestion of the cellulosic components in an attempt to produce more ethanol.

\section{SAMPLES COLLECTION AND HIGH PERFORMANCE LIQUID CHROMATOGRAPHY (HPLC) ANALYSES}

The samples were taken at 0, 6, 12, 24, 48, 72, 96 and $120 \mathrm{~h}$. Three $\mathrm{mL}$ samples were pipetted aseptically and centrifuged at $14000 \mathrm{rpm}$ for $5 \mathrm{~min}$. The supernatant were then filtered using $0.45 \mu \mathrm{m}$ nylon filters and stored in 2 separate $1.5 \mathrm{~mL}$ tubes at $-20^{\circ} \mathrm{C}$ before further analyses were performed. The samples were analysed using high performance liquid chromatography (HPLC) for residual glucose, ethanol and acetic acid. The HPLC system (Shimadzu/LC-20A, Tokyo, Japan) used in this study was equipped with a column oven (CTO-20A), refractive index detector (RID-10A), isocratic pump (LC-20AT) and computer controller. The separation and analysis of ethanol and other fermentation constituents were done on a BioRad Aminex HPX-87H column $(150 \times 7.8 \mathrm{~mm}$; Bio-Rad, CA, USA), using $0.005 \mathrm{M} \mathrm{H}_{2} \mathrm{SO}_{4}$ as the mobile phase at a rate flow of $0.8 \mathrm{~mL} / \mathrm{min}$, a $20 \mu \mathrm{L}$ injection volume and a column temperature of $65^{\circ} \mathrm{C}$ (Vincent et al. 2011b).

\section{RESULTS AND DISCUSSION}

Simultaneous saccharification and fermentation (SSF) is a method of choice for the production of bioethanol from lignocellulosic biomass (Vincent et al. 2014, 2011b;). This method has been studied for several decades and shows great potential for mass production of bioethanol (Isci et al. 2008; Splinder et al. 1991). During SSF, enzymatic saccharification of cellulose by cellulolytic enzymes and fermentation of the sugar produced by the saccharification reaction occurs simultaneously in the same vessel, reducing the end-product inhibition of enzymatic hydrolysis and also the overall cost. Another advantage of using SSF is the reduction of potential microbial contamination with the presence of ethanol in the culture medium (Wu \& Lee 1998).

In this study, we modified the conventional SSF procedure to a sequential process which we refer to as sequential saccharification and simultaneous fermentation (SSSF) to further reduce the organic load in starchy lignocellulosic residues such as sago hampas and ultimately attempt to produce more bioethanol. The term sequential refers to a two-step process of enzymatic hydrolysis in which the first stage is the amylolytic step and the second stage is the cellulolytic step, both occurring in one vessel. During the amylolytic stage, amylase was the enzyme used to catalyse the breakdown of starch into glucose, by acting on the 1,4- $\alpha$-D-glycosidic linkages to produce glucose (Aiyer 2005), while cellulase was added during the cellulolytic stage to further degrade the cellulosic components in sago hampas into glucose by breaking the 1,4- $\beta$-D-glycosidic linkages (Vincent et al. 2014). SSSF was carried out on sago hampas at $2.5 \%(\mathrm{w} / \mathrm{v})$ and $5.0 \%(\mathrm{w} / \mathrm{v})$ loading.

Table 1 shows the compositional analyses of sago hampas used in this study. From the results, the starch content in sago hampas was $58.0 \%$ (w/w), while the cellulose content was $23.5 \%(\mathrm{w} / \mathrm{w})$. The high percentages of starch and cellulosic component make sago hampas a prime material for amylolytic and cellulolytic hydrolyses.

TABLE 1. Compositional analysis of sago hampas

\begin{tabular}{lc}
\hline Sago hampas component & $\%$ \\
\hline Starch & $58.0 \pm 1.2$ \\
Cellulose & $23.5 \pm 1.0$ \\
Hemicellulose & $8.19 \pm 0.2$ \\
Lignin & $6.3 \pm 1.0$ \\
Ash & $1.7 \pm 0.1$ \\
Other & $2.3 \pm 0.2$ \\
\hline
\end{tabular}

Amylase was introduced into the fermentation medium to digest the starch on the first day of SSSF. The fermentation medium was left for 3 days to allow the reaction of amylase and starch. On the third day, cellulase was introduced to digest the remaining cellulose and the fermentation was continued until the fifth day of SSSF. The resultant sugar released during both stages was converted into ethanol by using $S$. cerevisiae. Products of the SSSF process were measured via high performance liquid chromatography (HPLC) for residual glucose and ethanol.

From the results shown in Figures 2 and 3, the highest ethanol production was detected in $5.0 \%(\mathrm{w} / \mathrm{v}) \mathrm{sago}$ hampas at $14.13 \mathrm{~g} / \mathrm{L}$ or $77.43 \%$ theoretical ethanol yield (TEY) at $96 \mathrm{~h}$. This is significantly higher than ethanol production in the samples with $2.5 \%$ (w/v) sago hampas, which was only $6.45 \mathrm{~g} / \mathrm{L}(69.24 \% \mathrm{TEY})$. For the experiment with $2.5 \%(\mathrm{w} / \mathrm{v})$ sago hampas, ethanol production increased significantly to $69.24 \%$ TEY from 6 to $24 \mathrm{~h}$, decreasing slightly thereafter until $72 \mathrm{~h}$ to $59.25 \% \mathrm{TEY}$. These differences in the peak times for ethanol productions were due to the glucose concentration present in both fermentation media. At $5.0 \%(\mathrm{w} / \mathrm{v})$ sago hampas, glucose concentration was higher (Figure 3) and more time was required for the $S$. cerevisiae to fully converted them into ethanol, while, the broth with $2.5 \%(\mathrm{w} / \mathrm{v})$ sago hampas has lower glucose concentration, requiring a shorter period to fully convert the glucose into ethanol. Ethanol production increased again at $96 \mathrm{~h}(67.64 \% \mathrm{TEY})$ after the addition of cellulase at $72 \mathrm{~h}$. Ethanol production profile for the experiment with $5.0 \%(\mathrm{w} / \mathrm{v})$ sago hampas was very similar to the previous set, with concentration increasing rapidly from 6 to $24 \mathrm{~h}$ (at $75.86 \%$ TEY). The ethanol concentration also started to decline after $24 \mathrm{~h}$ by $4.62 \%$ TEY at $72 \mathrm{~h}$. At $96 \mathrm{~h}$, ethanol production slightly increased to $77.43 \%$ TEY and decreasing again to $75.15 \%$ TEY at $120 \mathrm{~h}$. 
Time course of ethanol production (theoretical yield)

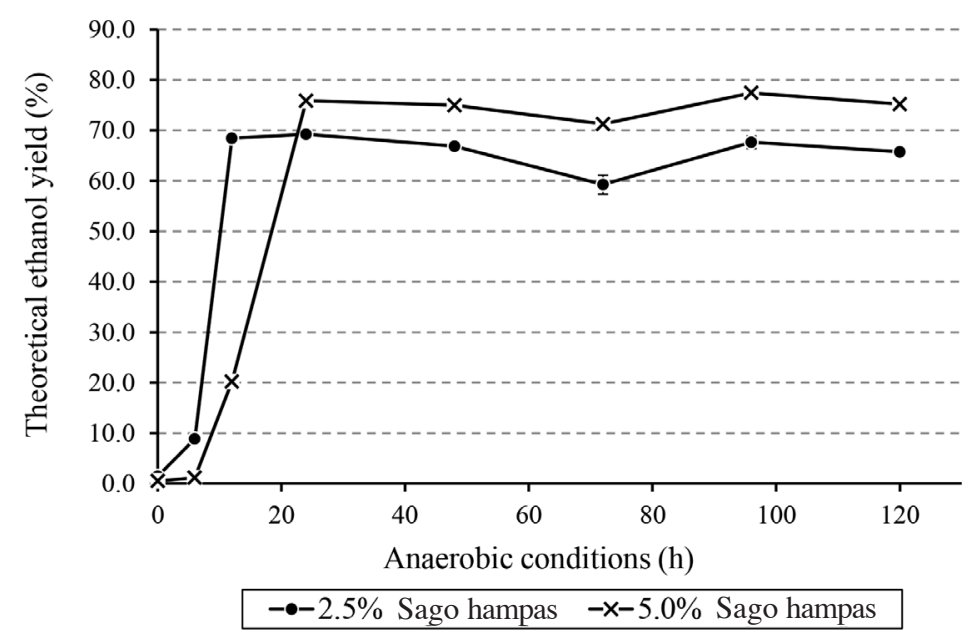

FIGURE 2. Graph showing the time course of theoretical ethanol yield production



FIGURE 3. Graph showing the time course of ethanol and glucose production

In both experiments, with two different sago hampas loading, ethanol concentration decreased at $72 \mathrm{~h}$ and slightly increasing at $96 \mathrm{~h}$. This was due the addition of cellulose at $72 \mathrm{~h}$ of the fermentation which marked the starting of the second stage of SSSF. From the results, there were apparent increases of ethanol concentration after the addition of cellulose, indicating efficient cellulolytic activities on the cellulose fibre. However, the overall ethanol yield at $120 \mathrm{~h}$ was lower than the highest concentration at $24 \mathrm{~h}$.

The monitoring of glucose concentration in the fermentation broth during anaerobic fermentation is important as glucose concentration affects the rate of ethanol production (Periyasamy 2009). Furthermore, based on a previous study conducted by Altintas et al. (2002), glucose concentration is proportional to the ethanol production. Based on the graph in Figure 3, the highest glucose concentration was detected in $5.0 \%(\mathrm{w} / \mathrm{v})$ sago hampas at $40.15 \mathrm{~g} / \mathrm{L}(6 \mathrm{~h})$. Glucose was still detected at $12 \mathrm{~h}$ because longer period was required for the amylase to fully convert all the starch into glucose to be used by $S$. cerevisiae. By $24 \mathrm{~h}$, no glucose was detected, indicating full utilization by the yeast. While in $2.5 \%(\mathrm{w} / \mathrm{v})$ sago hampas, starch was rapidly converted into glucose and consumed by $S$. cerevisiae, as indicated by the absence of glucose at $12 \mathrm{~h}$.

Acetic acid concentrations were also measured by using HPLC. Based on the graph in Figure 4, the highest acetic acid concentration was recorded in the broth with $5.0 \%(\mathrm{w} / \mathrm{v})$ sago hampas at $0.96 \mathrm{~g} / \mathrm{L}$ compared with $2.5 \%(\mathrm{w} / \mathrm{v})$ at $0.72 \mathrm{~g} / \mathrm{L}$. For the broth with $2.5 \%(\mathrm{w} / \mathrm{v})$ sago hampas, the acetic acid concentrations increased 
Time course of acetic acid production

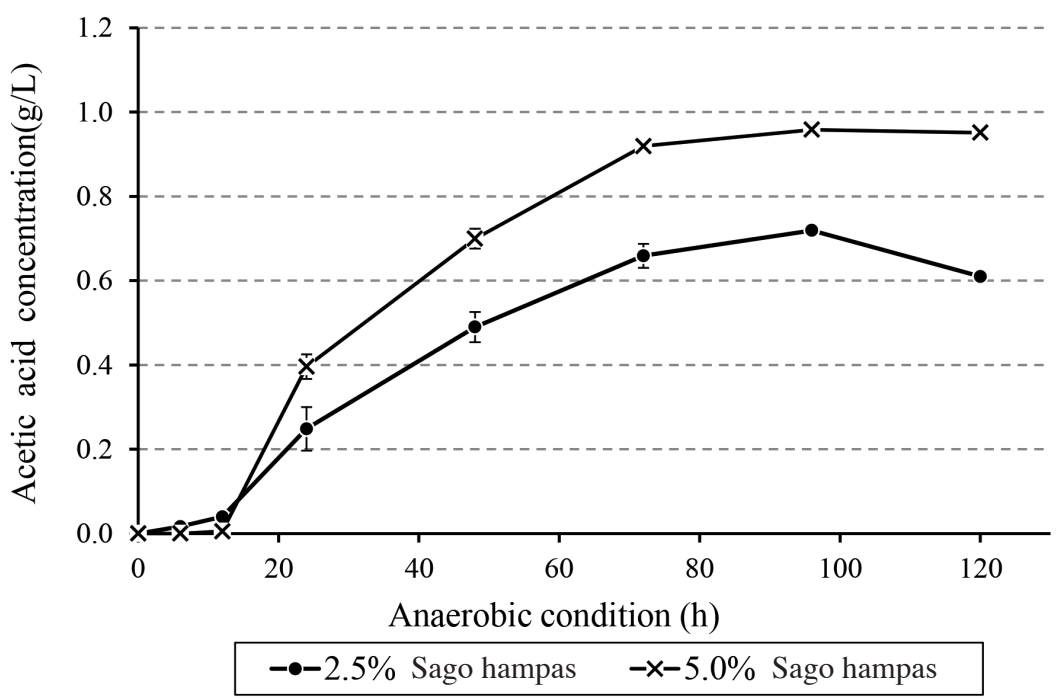

FIGURE 4. Graph showing the time course of acetic acid production

from $0 \mathrm{~h}(0 \mathrm{~g} / \mathrm{L})$ to its peak at $72 \mathrm{~h}$. After $72 \mathrm{~h}$, the acetic acid concentration slowly decreased to $0.61 \mathrm{~g} / \mathrm{L}$ at 120 h. The acetic acid profile for the broth with $5.0 \%(\mathrm{w} / \mathrm{v})$ sago hampas was almost similar with the acetic acid concentration increasing at $12 \mathrm{~h}$ onwards until $72 \mathrm{~h}$. After $72 \mathrm{~h}$, acetic acid concentration started to decrease to $0.95 \mathrm{~g} / \mathrm{L}$ at $120 \mathrm{~h}$. Although the presence of acetic acid is not as significant as ethanol, it is nevertheless an important indicator to evaluate the efficiency of biomass hydrolysis, as more acetic acid produced indicates constant degradation of lignocellulosic materials during SSSF. In addition, according to Yang et al. (2010), the rate of acetic acid generated is related to the production of fermentable sugars.

\section{CONCLUSION}

From this study, we have demonstrated that bioethanol can be produced from sago hampas via sequential saccharification and simultaneous fermentation (SSSF) using amylase, cellulase and $S$. cerevisiae. From this study, the results showed that $5.0 \%(\mathrm{w} / \mathrm{v})$ sago hampas loading was more effective in producing higher ethanol yield which was at $77.43 \%$ TEY compared with $2.5 \%$ (w/v) which was only $69.24 \%$ TEY. This study also showed that it is feasible to increase bioethanol production via SSSF. We recommend that future studies be performed by using different amylase and cellulase enzyme dosages to compare and determine the best enzyme load combinations to increase ethanol yield.

\section{ACKNOWLEDGEMENTS}

This project was funded by a research grant from the UNIMAS Tun Openg Sago Chair grant (ORC/12/011(08) and FRGS grant (FRGS/SG(05)/969/2013(10).

\section{REFERENCES}

Adeni, D.S.A., Abd-Aziz, S., Bujang, B. \& Hassan, M.H. 2010 Review: Bioconversion of sago residue into value added products. African Journal of Biotechnology 9(14): 2016-2021.

Aiyer, P.V. 2005. Amylases and their applications. African Journal of Biotechnology 4(13): 1525-1529.

Altintas, M., Ulgen, K.O., Kirdar, B., Onsan, Z.I. \& Oliver, S.G. 2002. Improvement of ethanol production from starch by recombinant yeast through manipulation of environmental factors. Enzyme and Microbial Technology 31: 640-647.

Bujang, K. \& Ahmad, F.B. 2000. Country report of Malaysia. Production and utilization of sago starch in Malaysia. International Sago Seminar. pp. 1-8.

Bujang, K., Apun, K. \& Salleh, M.A. 1996. A study in the production and bioconversion of sago waste. In Sago - The Future Source of Food and Feed, edited by Jose, C. \& Rasyad, A. Indonesia: Riau University Press. pp. 195-201.

Cervero, J.M., Skovgaard, P.A., Felby, C., Sorensen, H.R. \& Jorgensen, H. 2010. Enzymatic hydrolysis and fermentation of palm kernel press cake for production of bioethanol. Enzyme and Microbial Technology 46: 177-184.

Chew, T.Y. \& Shim, Y.L. 1993. Management of sago processing wastes. In Waste Management in Malaysia - Current Status and Prospects for Bioremediation, edited by Yeoh, B.G., Chee, K.S., Phang, S.M., Isa, Z., Idris, A. \& Mohamed, M. Kuala Lumpur: Ministry of Science, Technology and the Environment.

Isci, A., Himmelsbach, J.N., Strohl, J., Pometto, A.L., Raman, D.R. \& Anex, R.P. 2008. Pilot-scale fermentation of aqueousammonia-soaked switchgrass. Applied Biochemistry and Biotechnology 157(3): 453-462.

Periyasamy, S. 2009. Production of bioethanol from sugar molasses using Saccharomyces cerevisiae. Modern Applied Science 3(8): 32-37.

Sluiter, A., Hames, B., Ruiz, R., Scarlata, C., Sluiter, J. \& Templeton, D. 2005. Determination of ash in biomass. http:// www.nrel.gov/docs/gen/fy08/42622.pdf.

Spindler, D.D., Wyman, C.E. \& Grohmann, K. 1991. The simultaneous saccharification and fermentation of pretreated 
woody crops to ethanol. Applied Biochemistry and Biotechnology 28 \& 29: 773-786.

Undersander, D., Mertens, D.R. \& Thiex, N. 1993. Forage analyses procedures. http://www.foragetesting.org/files/ LaboratoryProcedures.pdf.

Vincent, M. 2010. Sequential saccharification and fermentation of corn stover for the production of fuel ethanol using wood-rot fungi, Saccharomyces cerevisiae and Escherichia coli K011. $\mathrm{PhD}$ Thesis. Iowa State University, Iowa, US (unpublished).

Vincent, M., Pometto III, A.L. \& van Leeuwen, J. (Hans). 2014. Ethanol production via simultaneous saccharification and fermentation of sodium hydroxide treated corn stover using Phanerochaete chrysosporium and Gloeophyllum trabeum. Bioresource Technology 158: 1-6.

Vincent, M., Anthony, L. \& van Leeuwen, J. (Hans). 2011a. Evaluation of potential fungal species for the in situ simultaneous saccharification and fermentation (SSF) of cellulosic materials. Malaysian Journal of Microbiology 7(3): 120-138.

Vincent, M., Anthony, L. \& van Leeuwen, J. (Hans). 2011b. Simultaneous saccharification and fermentation of ground corn stover for the production of ethanol using Phanerocheate chrysoporium, Gloeophyllum trabeum, Saccharomyces cerevisiae and Escherichia coli K011. Journal of Microbiology and Biotechnology 21(7): 703-710.

Vogel, K.P., Pedersen, J.F., Masterson, S.D. \& Toy, J.J. 1999. Evaluation of a filter bag system for NDF, ADF and IVDMD forage analysis. Crop Science 39: 276-279.

Wu, Z. \& Lee, Y.Y. 1998. Non-isothermal simultaneous saccharification and fermentation for direct conversion of lignocellulosic biomass to ethanol. Applied Biochemistry and Biotechnology 70-72: 479-492.
Yamashita, Y., Sasaki, C. \& Nakamura, Y. 2010. Development of efficient system for ethanol production from paper sludge pretreated by ball milling and phosphoric acid. Carbohydrate and Polymer 79: 250- 254

Yang, S., Land, M.L., Klingeman, D.M., Pelletier, D.A., Lu, T.S., Martin, S.T., Guo, H., Smith, J.C. \& Brown, S.D. 2010. Paradigm for industrial strain improvement identifies sodium acetate tolerance loci in Zymomonas mobilis and Saccharomyces cerevisiae. Applied Biological Sciences 107(23): 10395-10400.

Zakaria, S., Roslan, R., Amran, U.A., Chia, C.H. \& Bakaruddin, S.B. 2014. Characterization of residue from EFB and kenaf core fibres in the liquefaction process. Sains Malaysiana 43(3): 429-435.

Zakaria, S., Ahmadzadeh,A. \& Roslan, R. 2013. Flow properties of novolak-type resin made from liquefaction of oil palm empty fruit bunch (EFB) fibres using sulfuric acid as a catalyst. Bioresources 8(4): 5884-5894.

Department of Molecular Biology

Faculty of Resource Science and Technology

Universiti Malaysia Sarawak

94300 Kota Samarahan, Sarawak

Malaysia

*Corresponding author; email: vmicky@frst.unimas.my

Received: 22 July 2014

Accepted: 13 January 2015 